\title{
CAPITAL MOBILITY, FISCAL POLICY \\ AND GROWTH UNDER SELF-FINANCING \\ OF HUMAN CAPITAL FORMATION
}

Willem H. Buiter

Kenneth M. Kletzer

Working Paper No. 5120

\section{NATIONAL BUREAU OF ECONOMIC RESEARCH 1050 Massachusetts Avenue \\ Cambridge, MA 02138 \\ May 1995}

This paper is part of NBER's research program in International Finance and Macroeconomics. Any opinions expressed are those of the authors and not those of the National Bureau of Economic Research.

(C) 1995 by Willem H. Buiter and Kenneth M. Kletzer. All rights reserved. Short sections of text, not to exceed two paragraphs, may be quoted without explicit permission provided that full credit, including () notice, is given to the source. 


\title{
CAPITAL MOBILITY, FISCAL POLICY AND GROWTH UNDER SELF-FINANCING OF HUMAN CAPITAL FORMATION
}

\begin{abstract}
This paper considers the effects of fiscal and financial policy on economic growth in open and closed economies, when human capital formation by young households is constrained by the illiquidity of human wealth. Both endogenous and exogenous growth versions of the basic OLG model are analyzed. We find that intergenerational redistribution policies that discourage physical capital formation may encourage human capital formation. Despite common technologies and perfect international mobility of financial capital, the non-tradedness of human capital and the illiquidity of human wealth make for persistent differences in productivity growth rates (in the endogenous growth version of the model) or in their levels (in the exogenous growth version). We also consider the productivity growth (or level) effects of public spending on education and of the distortionary taxation of financial asset income.
\end{abstract}

Willem H. Buiter

Faculty of Economics \& Politics

University of Cambridge

Austin Robinson Building

Sidgwick Avenue

Cambridge, CB3 9DD

UNITED KINGDOM

and NBER
Kenneth M. Kletzer

Department of Economics

University of California

Santa Cruz, CA 95064 


\section{INTRODUCTION.}

Among the broad range of topics in economic analysis and policy that attracted the attention and talents of Doug Purvis, two themes appear frequently throughout his work. These are the consequences of international capital mobility and the impact of fiscal policies on the allocation of resources and economic growth. Doug made significant contributions, both in the literature of academic economics and in his contributions to the Canadian economic policy debate, to thinking about the effects of the deficit-financing of public spending on private sector activity in an open economy. In particular, he chose as the theme of his 1985 Innis lecture published in this journal (Purvis [1985]) the role of public sector budget deficits in stabilization and the potential for financial crowding out of private accumulation and consumption when financial capital is internationally mobile. One point that Doug noted was the importance of distinguishing human wealth from financial wealth in analyzing the impact of fiscal policies on asset accumulation and growth. In Purvis [1975], an unpublished working paper, he undertook an early effort to highlight the importance of redistribution between owners of these two types of assets for the effects of deficit-financing policies.

We pursue this theme by considering the effects of fiscal policies on factor accumulation and economic growth in a world economy with perfect international financial capital mobility and costless international tradability of physical capital goods but with imperfect collateralizability of human wealth (a domestic capital market imperfection) and restricted international tradability of human capital goods. One question we address is how imperfections in domestic capital markets and restrictions on the international tradability of human capital goods can give rise to persistent international differences in levels and growth rates of labor productivity even though there is free trade in final goods and services, financial and physical capital assets and unrestricted and costless international diffusion of technological knowledge. The second issue we consider are the effects of fiscal policies on economic growth and growth differentials or rates of convergence in an integrated world economy when households are constrained in their abilities to reallocate their 
portfolios among financial claims and human wealth.

Much of the literature of the past several years on endogenous growth sought to explain persistent international productivity growth rate differentials by increasing returns to scale or by differences in technology, factor endowments, initial conditions and industrial structure. ${ }^{1}$ With constant returns to scale, free international trade in all final goods and services, costless international reallocation of physical capital goods, perfect international financial capital mobility and costless technology transfer, these models imply that productivity growth rates and levels would immediately converge across borders $^{2}$. If strictly convex adjustment costs to international capital stock reallocation are added, growth rates and levels of productivity would not immediately be identical, but convergence would take time and permanent differences would still disappear. Without increasing returns to scale, one way to derive persistent or permanent international productivity growth rate differentials is to reintroduce the possibility that trading opportunities are not complete. ${ }^{3}$

Our approach extends our earlier emphasis on the inability of households to trade all inputs to the accumulation of skills or human capital. To avoid confusion, henceforth the expression human wealth is restricted to mean the present discounted value of future labor earnings. Thus the asset human wealth is well-defined even if there is no augmentable human factor of production or labor input. The terms human capital or skill(s) will refer to the augmentable labor input, that is, the human factor of production that enters as an argument in the production function and that can be accumulated through training, education, learning by doing etc.

In Buiter and Kletzer [1991, 1993], productivity growth differentials are generated by the introduction of a non-traded essential input into the formation of human capital by households in a model with heterogeneous human and physical capital. ${ }^{4}$ This input is time spent in one's own education that has an alternative use as intrinsically-valued leisure time. We show that differences in the underlying determinants of household saving give rise to international productivity growth differentials despite perfect financial and physical capital mobility, common technologies and constant returns to scale. These determinants are household taste parameters, the subjective rate of discount and intertemporal elasticity of substitution, and fiscal policies. In an overlapping generations model without an operative bequest motive, lump-sum fiscal policies that redistribute between generations, such as public deficit and debt policies or unfunded social security retirement schemes, can 
give rise to permanent international productivity growth differentials.

The present paper retains the assumption that human capital is nontradable. The human capital or skill accumulation technology is simplified, however, by assuming that all inputs into the production of additional human capital are traded. ${ }^{5}$ The implicit domestic transformation curve between human capital and physical capital is concave toward the origin, however. Except for the special case of a linear transformation locus, shifting resources from the production of additional physical capital goods to the accumulation of human capital is subject to increasing marginal costs.

While retaining from our earlier paper a weakened version of the assumption of non-tradedness of human capital, the present paper emphasizes the fact that it is easier to borrow to finance investment in physical capital goods than to finance investment in skills. This is a "domestic" credit market imperfection: it is present in a closed economy as well. The reason is that, for informational, legal or other institutional reasons, human wealth makes poor collateral.

An individual educates herself when young, increasing the stock of human capital whose service flow she can trade on the labor market in the future. The constraint is that she is unable to borrow against future labor earnings to finance the purchase of (traded) educational inputs during youth: education must be self-financed. We use an overlapping generations model and assume that education generates a positive externality in that the average level of human capital for a generation is inherited, without compensation, by the next generation. This externality is restricted to the national population: human capital is a form of national common knowledge that is non-traded internationally.

The first part of the paper shows how permanent international labor productivity growth differentials arise when the self-financing constraint is binding in at least one country. Permanent differences in growth rates are possible if there are constant returns to scale in the augmentable inputs to production of final goods, physical and human capital. If there are decreasing returns to scale with respect to these two accumulable factors (perhaps, through the introduction of a third exogenously growing factor, such as "raw" labor), then permanent differences arise in the steady-state levels of human capital per household and labor productivity. In that case, countries can experience different rates of convergence to the steady state. ${ }^{6}$ We demonstrate how differences in tastes and fiscal policy parameters affect the permanent growth rate differential between countries when production displays constant returns 
to augmentable factors and the convergence rate when there are decreasing returns to augmentable factors. The fiscal policies we consider include lumpsum intergenerational redistribution, residence-based taxes on the returns to financial saving by households and public spending on inputs to education, provided free of charge to the young. ${ }^{7}$

The rest of the paper analyzes how fiscal policies affect the growth path for a closed economy. The switch from a two-country model to a single-country model is made for analytical and expositional simplification. The results of a small change (that is, a perturbation) in fiscal policies on the long-run growth rate for the closed economy with constant returns to augmentable factors, tell us how the same policy changes pursued by one government would affect the differential performance of the perturbed economy in a twocountry model in a "symmetric equilibrium", that is, one in which initial conditions and the initial set of policies and taste parameters are identical across countries. With decreasing returns to augmentable factors, the same proposition holds with respect to levels in the steady state and to rates of convergence if initial conditions are identical across borders in the analog two-country version. Although less precise, the closed-economy model still provides qualitative information about how the rate of convergence between countries and long-run growth rates or levels of output per capita are affected by national fiscal policies in the presence of integrated financial markets and self-financing constraints on human capital accumulation.

Other authors have considered the role of capital or credit market imperfections in explaining permanent growth rate differentials or slow convergence to steady-state growth paths in endogenous growth models. ${ }^{8}$ The closest in spirit to our model is one by De Gregorio and Kim [1994] that analyzes the consequences of a self-financing constraint facing households in an overlapping generations model with heterogeneous agents. Households have different abilities for using inputs to education for creating human capital (skills). Our model is set up a bit differently, but the main difference is that we consider the consequences of fiscal policies for growth rates and differentials in rates of growth. Barro, Mankiw and Sala-i-Martin [1992] assume that physical capital goods are costlessly traded internationally. Human capital can be costlessly transformed into physical capital: the domestic transformation locus between physical and human capital is linear. As regards financial markets, they consider both the case where borrowing can be collateralized against all assets (the sum of human wealth and physical capital) and the case where it can be collateralized against physical capital only. In the former 
case, total wealth (human wealth plus physical capital minus private debt) is restricted to be non-negative. In the latter case total non-human wealth (physical capital minus private debt) is restricted to be non-negative. They show that in their model, which assumes decreasing returns to scale with respect to augmentable inputs, convergence rates are lower when the borrowing constraint is binding. The same dynamics would arise in our model when the self-financing constraint is not binding on youthful households, in the special case where the domestic transformation locus between physical and human capital is linear.

The outline of the rest of the paper is as follows. Section 2 presents the model. Section 3 discusses the implications of self-financing for the impact of international differences in policies or tastes on productivity growth rate differentials. Section 4 presents a closed-economy model with constant returns to scale and shows how (lump-sum) budgetary policies affect long-run factor accumulation and growth rates. In Section 5, we introduce decreasing returns to scale with respect to augmentable factors and analyze how budgetary policies affect the steady state and convergence rate. The last section concludes.

\section{THE MODEL.}

\subsection{Household behavior.}

Households make decisions concerning consumption, labor supply, human capital formation and financial portfolio allocation. The household sector in each country is represented using a three-period overlapping generations model. In our discussion of international productivity growth differentials, we only derive the household behavior for the home country. The use of the superscript * indicates any foreign parameters or variables throughout. While there are many identical consumers in each generation, we only use an additional subscript once to designate individual consumers where it is needed to avoid ambiguity. In the first period of her life ('youth'), each consumer born in period $t$ is endowed with $h_{t}^{0}>0$ units of human capital. "Raw" labor plays no role in our model, there is no labor-leisure choice and education does not require the input of "own" time. The endowment of time is therefore suppressed in what follows. Her labor supply in period $t$ equals $h_{t}^{0}$ when measured in efficiency units. She can choose to allocate the income 
she earns in period $t$ between current consumption, $c_{t}^{0}$, saving for future consumption, or the purchase of an education. The education process uses material inputs during the first period of the household's life to increase the stock of human capital, $h_{t}^{1}$, available during the second period of life ('middle age'). That is, $h_{t}^{1}$ is the endowment of labor in efficiency units available at time $t+1$ to the household born in period $t$. The production of human capital can use either privately supplied or publicly provided inputs. In general, these could be imperfect substitutes or even complements. We assume that public and private expenditures are perfect substitutes in the augmentation of human capital stocks for the sake of simplicity. ${ }^{9}$ The production function for human capital formation is assumed to have take the simple form given in equation $1(1)$.

$$
h_{t}^{1}=\delta h_{t}^{0}\left[1+\xi\left(\frac{m_{t}+g_{t}}{\delta h_{t}^{0}}\right)\right]
$$

Here $m_{t}$ represents private educational purchases by the household born at date $t$ while young, and $g_{t}$ denotes public education spending on the same household at date $t$. The function, $\xi(\cdot)$, is non-negative, increasing, strictly concave and twice-continuously differentiable, and $\xi(0)=0$. The parameter $\delta$ allows for the possibility that human capital can depreciate. We assume that $0<\delta \leq 1$.

We assume that educational expenditures, both publicly and privately funded, are private goods, except that public consumption cannot be resold. Thus, public expenditure on education benefiting a given individual can only be enjoyed by that individual: it is excludable and rival, but cannot be resold by the recipient. For simplicity, the young are assumed to pay no taxes and to receive no transfer payments other than the benefits from the "transfer in kind" $g_{t}$.

We assume that human capital is passed on to the next generation and that there is a domestic externality in the intergenerational transmission of human capital. Formally, we model this by assuming that $h_{j t}^{0}$, the amount of time measured in efficiency units (human capital) which the $j^{\text {th }}$ household of generation $t$ is endowed with at birth, is given by the average amount of human capital achieved by the previous generation during middle age. That is, letting $N_{t}$ denote the number of households-consumers in period $t$,

$$
h_{j t}^{0}=\frac{1}{N_{t-1}} \sum_{i=1}^{N_{t-1}} h_{i t-1}^{1}
$$


It is clear that $h_{j t-1}^{1}$ is non-rival with respect to the levels of human capital achieved in period $t$ by members of generation $t$. If generation $t$ is larger, more members of generation $t$ will benefit from the higher average level of education achieved by the previous generation. The externality (and source of inefficiency) arises because we also assume that members of generation $t-1$ cannot exclude individuals born in period $t$ from benefitting from the accumulation of human capital in period $t-1$, or charge them for it. ${ }^{10}$

Our human capital accumulation mechanism extends the one developed by Lucas [1988], following Razin [1972] and Uzawa [1965]. Our specification here is a special case of the one used in Buiter and Kletzer [1991 and 1993]. ${ }^{11}$ There is an empirical basis for making our assumption of an intergenerational externality in human capital accumulation. Borjas [1992] presents empirical evidence for human capital externalities by showing that the average level of human capital of an individual's ethnic group for the previous generation positively affects the individual's productivity level. It also solves a technical problem, first highlighted by Jones and Manuelli [1990], of endowing new generations in an OLG model with an asset whose value will grow at the endogenously determined growth rate.

We have included the possibility that human capital depreciates as it is passed between generations in the specification of the production function for human capital formation in equation 1. An alternative specification would be to assume that an individual's human capital does not depreciate over her lifetime but that it is passed on to the next generation in a depreciated amount. We place depreciation in equation 1 rather than in equation 2 only for algebraic convenience.

During middle age, the household born at date $t$ chooses how much to consume, $c_{t}^{1}$, and supplies her entire endowment of labor in efficiency units, $h_{t}^{1}$, inelastically in the labor market. The middle-aged may also pay lumpsum taxes (receive transfers if negative) denoted $\tau_{t}^{1}$.

In the last period of life ('old age'), households do not work and would not choose to educate themselves (since they would realize no return from doing so ${ }^{12}$ ). At time $t+2$, the old generation born at $t$ consumes $c_{t}^{2}$, which equals the value of the resources they carry into old age through saving in the first two periods of their lives, minus any lump-sum taxes $\tau_{t}^{2}$ paid in period $t+2$.

We make an additional assumption which is key to our results about productivity growth differentials. This is that households are unable to borrow against their future income (labor income or transfers net of taxes) 
to finance education when young. There is a capital market imperfection such that educational expenditures by the young can only be financed out of concurrent labor earnings. The belief that capital market imperfections constrain human capital accumulation is widespread and supported by empirical studies of educational attainment. Becker [1975] discusses borrowing constraints in theoretical models of human capital accumulation at length. Recent empirical evidence that capital market imperfections constrain individuals' educational attainments is provided by Behrman, Kletzer, McPherson and Schapiro [1992] and by Cameron and Heckman [1992] from individual survey data. Both studies find that family financial resources are a significant determinant of education levels after accounting for a large number of other influences including parents' educational attainment, individual characteristics and measures of ability. One theoretical reason that households may be unable to borrow against future labor income to finance either current consumption or investments in human capital is that prohibitions against slavery and indentured servitude and bankruptcy laws restricting the ability to attach wages reduce or eliminate the ability of agents to use human wealth for loan collateral. ${ }^{13}$. Asymmetric information about labor quality or effort can also turn human wealth into inferior collateral. A separate argument must be made, however, to extend the imperfect collateralizability of human wealth to future transfer payments (net of future taxes).

Formally, each household of generation $t(t \geq 0)$ takes interest rates, wages, taxes and public spending on education as given and maximizes its lifetime utility function $U_{t}$, given by

$$
U_{t}=u\left(c_{t}^{0}\right)+\beta u\left(c_{t}^{1}\right)+\beta^{2} u\left(c_{t}^{2}\right)
$$

14

with respect to $m_{t}, c_{t}^{0}, c_{t}^{1}$ and $c_{t}^{2}$, subject to the constraints given in equations 4,5 and 6 and the usual non-negativity constraints.

$$
\begin{gathered}
\left(1+r_{t+1}-\theta_{t+1}\right)\left(m_{t}+c_{t}^{0}-h_{t}^{0} w_{t}\right)+c_{t}^{1}+\tau_{t}^{1}+\left(1+r_{t+2}-\theta_{t+2}\right)^{-1}\left(c_{t}^{2}+\tau_{t}^{2}\right) \leq h_{t}^{1} w_{t+1} \\
h_{t}^{1}=\delta h_{t}^{0}\left[1+\xi\left(\frac{m_{t}+g_{t}}{\delta h_{t}^{0}}\right)\right] \\
m_{t}+c_{t}^{0} \leq h_{t}^{0} w_{t}
\end{gathered}
$$


$c_{t}^{0}, c_{t}^{1}, c_{t}^{2}$, and $m_{t} \geq 0$. At the initial date, $t=0, h_{0}^{0}>0$.

Equation 4 is the lifetime budget constraint of a representative member of generation $t . w_{t+1}$ is the wage paid per unit of efficiency labor in period $t+1$. The before-tax interest factor on loans from period $t$ to period $t+1$ is $1+r_{t+1} . \theta_{t}$ is the period $t$ residence-based tax rate on all non-human asset income in the home country. It is therefore also the subsidy rate to borrowing by domestic residents, which can only be borrowing by the middle-aged, because, by assumption, the young cannot borrow and because equation 4 already incorporates the implicit assumption that lenders are smart enough not to lend to the old (who would not be around to repay such loans). We assume that $\tau_{t}^{1}$ and $\tau_{t}^{2}$ are restricted so that equation 4 can be satisfied for non-negative values of $c_{t}^{1}, c_{t}^{2}$ and $m_{t}$.

When there are decreasing returns to scale $(\alpha+\gamma<1)$, the pure profits that are generated when physical and human capital are paid their marginal products, must be assigned. We assume that all pure profits accrue to the owners of physical capital. For simplicity, one unit of equity (ownership claim to the pure profits produced that period) is associated with each unit of physical capital.

Inequality 6 represents our credit market imperfection: the wage earnings in period $t$ must be at least as great as the sum of $c_{t}^{0}$ and $m_{t}$. If 6 is not binding in a household optimum, then the household saves while young, carrying financial wealth over into middle age.

Equation (7) gives the intergenerational transmission of human capital.

$$
h_{t}^{0}=h_{t-1}^{1}
$$

Population is assumed to grow at a constant proportional rate:

$$
N_{t}=(1+n) N_{t-1} \quad n>-1 ; N_{0}>0 .
$$

The necessary conditions for the solution to the household optimization problem include equations 4 and 5 and the first-order conditions given in 9 and 10 .

$$
\begin{aligned}
& u^{\prime}\left(c_{t}^{1}\right)=\left(1+r_{t+2}-\theta_{t+2}\right) \beta u^{\prime}\left(c_{t}^{2}\right) \\
& u^{\prime}\left(c_{t}^{0}\right)=\beta u^{\prime}\left(c_{t}^{1}\right) w_{t+1} \xi^{\prime}\left(\frac{m_{t}+g_{t}}{\delta h_{t}^{0}}\right)
\end{aligned}
$$


If the self-financing constraint is not binding, then the set of equilibrium conditions for the household are completed by equation 11 and inequality 6 .

$$
1+r_{t+1}-\theta_{t+1}=w_{t+1} \xi^{\prime}\left(\frac{m_{t}+g_{t}}{\delta h_{t}^{0}}\right)
$$

Equation 11 implies that, when the self-financing constraint for human capital formation is not binding, the household's optimal choice of $m_{t}$ depends only on the interest rate, wage rate, initial endowment of human capital $\left(h_{t}^{0}\right)$ and the technology for producing human capital. It is independent of tastes, that is, the rate of time preference and other parameters of the utility function such as the intertemporal elasticity of substitution. If we added leisure to the arguments of the utility function in the model so that labor supply while young is no longer assumed to be perfectly inelastic, then labor-leisure choice would also have no effect on the household's choice of inputs to education as a fraction of $h_{t}^{\mathbf{0}}$.

If the constraint on borrowing against future labor income to finance educational expenditures is binding, then the inequality 12 and equation 13 complete the description of the household equilibrium.

$$
\begin{gathered}
1+r_{t+1}-\theta_{t+1} \leq w_{t+1} \xi^{\prime}\left(\frac{m_{t}+g_{t}}{\delta h_{t}^{0}}\right) \\
m_{t}+c_{t}^{0}=h_{t}^{0} w_{t}
\end{gathered}
$$

Equation 9 is the familiar martingale condition equating the marginal utility of consumption when middle-aged to the discounted marginal utility when old of the consumption allowed by financial savings. Equation 10 is the analogous condition equating the marginal utility of consumption when young to the discounted marginal utility of consumption in middle age permitted by allocating an additional unit of income to education in period $t$. Inequality 12 indicates that if the self-financing constraint is binding on the household's choice, then the marginal productivity of resources spent on education exceeds the return to the alternative opportunity of financial savings to finance consumption during middle age and old age.

We can see from 10 that the parameters of household tastes affect the rate of accumulation of human capital when the self-financing constraint is binding on private educational expenditures. Such parameters of the household utility function as the rate of time preference and the intertemporal elasticity of substitution in consumption affect the growth rate of human capital for 
the economy. We can add labor-leisure choice while young to the model by assuming that the human capital endowment of the young, $h_{t}^{0}$, can either be allocated to the labor market or enjoyed as leisure, $\ell_{t}^{0}$, rewriting the utility function as

$$
U_{t}=u\left(c_{t}^{0}, \ell_{t}^{0}\right)+\beta u\left(c_{t}^{1}\right)+\beta^{2} u\left(c_{t}^{2}\right)
$$

and the binding constraint on period $t$ spending as

$$
c_{t}^{0}+m_{t}=w_{t}\left(h_{t}^{0}-\ell_{t}^{0}\right)
$$

This formulation yields the first-order conditions for household optimization

$$
\begin{gathered}
u_{1}^{\prime}\left(c_{t}^{0}, \ell_{t}^{0}\right)=\beta u^{\prime}\left(c_{t}^{1}\right) w_{t+1} \xi^{\prime}\left(\frac{m_{t}+g_{t}}{\delta h_{t}^{0}}\right) \\
u_{1}^{\prime}\left(c_{t}^{0}, \ell_{t}^{0}\right)=w_{t}^{-1} u_{2}^{\prime}\left(c_{t}^{0}, \ell_{t}^{0}\right) .
\end{gathered}
$$

These imply that household preferences concerning the labor-leisure choice affect the accumulation rate of human capital when the self-financing constraint binds. We will use the more parsimonious model for the rest of the analysis.

\subsection{Firm behavior.}

Firms face competitive output and input markets and maximize profits. Nonnegative quantities of the two factors of production, human capital (or efficiency units of labor) and physical capital, can be varied costlessly. All firms are identical. The representative firm's production function exhibits non-increasing returns to its two factors of production, increasing in both its arguments, strictly concave, twice-continuously differentiable and satisfies the Inada conditions. Physical capital depreciates at a constant proportional rate $\vartheta, 0 \leq \vartheta \leq 1$.

The aggregate production function for the home country takes the CobbDouglas form given equation 14, which allows returns to scale (and to augmentable factors) to be either constant or decreasing. The representative domestic firm's first-order conditions equating the real interest rate to the marginal product of physical capital (net of depreciation) plus pure profits 
per unit of capital ${ }^{15}$, and the real wage to the marginal product of efficiency labor are given in equations 15 and 16 respectively. $Y$ denotes aggregate output, $K$ the aggregate physical capital stock, $H$ the aggregate stock of human capital and $k \equiv K / H$.

$$
\begin{gathered}
Y_{t}=H_{t}^{\alpha} K_{t}^{\gamma} \\
r_{t}=(1-\alpha) H_{t}^{\alpha} K_{t}^{\gamma-1}-\vartheta \\
w_{t}=\alpha H_{t}^{\alpha-1} K_{t}^{\gamma},
\end{gathered}
$$

where $\alpha>0, \gamma>0$ and $\alpha+\gamma \leq 1$.

The derivation of foreign country output, interest rate and wage rate is analogous. Note that the two countries are assumed to have identical production technologies. At the initial date, $t=0, K_{0}, K_{0}^{*}>0$.

\subsection{Government.}

In both countries the government spends on the education of its young, levies lump-sum taxes on the middle aged and the old, taxes all asset income of its residents at a proportional rate $\theta$, pays interest on its debt and borrows to finance any excess of current spending over current revenue. Government debt is single-period debt denominated in the traded output. The stock of home country government debt outstanding at the beginning of period $t$ is $B_{t}$. The home country government single-period budget identity is given in equation 17. The conventional solvency constraint, given in 18 , is assumed to apply. ${ }^{16}$ The foreign country counterparts are obvious and have been omitted.

$$
\begin{gathered}
B_{t+1} \equiv\left(1+r_{t}\right) B_{t}+g_{t} N_{t}-\tau_{t-1}^{1} N_{t-1}-\tau_{t-2}^{2} N_{t-2}-\theta_{t}\left(\frac{c_{t-2}^{2}+\tau_{t-2}^{2}}{1+r_{t}-\theta_{t}}\right) N_{t-2} \\
\lim _{j \rightarrow \infty} \prod_{i=0}^{j}\left(1+r_{t+i}\right)^{-1} B_{t+1+j}=0
\end{gathered}
$$

$B_{0}$ and $B_{0}^{*}$ are given. Equations 17 and 18 imply that the outstanding value of the public debt must equal the present discounted value of the future primary (non-interest) public sector budget surpluses. 
For notational convenience in what follows, we define

$$
T_{t} \equiv \tau_{t}^{1}+\frac{\tau_{t}^{2}}{1+r_{t+2}-\theta_{t+2}}
$$

$-T_{t}$ is the present value (discounted to period $t+1$ ) of the net lifetime lump-sum fiscal transfers to a member of generation $t$. Note that $\left(1+r_{t+1}-\right.$ $\left.\theta_{t+1}\right) g_{t}$, the period $t+1$ value of the public educational inputs spent on a member of generation $t$, can be viewed as income-in-kind, but is not a lumpsum transfer.

\subsection{Market Equilibrium.}

There is perfect international mobility of financial capital. In the absence of source-based taxes on capital income, the domestic and foreign before-tax interest rates and rates of return on fixed capital will be equalized.

$$
r_{t}=r_{t}^{*}
$$

The after-tax rates of return to private saving, $r_{t}-\theta_{t}$ in the home country and $r_{t}-\theta_{t}^{*}$ in the foreign country, however, can differ.

The labor markets clear in each country every period so that

$$
H_{t}=h_{t}^{0} N_{t}+h_{t-1}^{1} N_{t-1}=h_{t}^{0} N_{t}\left(\frac{2+n}{1+n}\right),
$$

and similarly for the foreign country.

Home country private financial wealth at the beginning of period $t+1$, $A_{t+1}$, is given by equation 22. $F_{t+1}$ denotes the net foreign assets of the home country at the beginning of period $t+1$. Note that $F \equiv-F^{*}$.

$$
\begin{aligned}
& A_{t+1} \equiv\left[w_{t} h_{t-1}^{1}-\tau_{t-1}^{1}-c_{t-1}^{1}+\left(1+r_{t}-\theta_{t}\right)\left(w_{t-1} h_{t-1}^{0}-m_{t-1}-c_{t-1}^{0}\right)\right] N_{t-1} \\
& +\left[w_{t} h_{t}^{0}-m_{t}-c_{t}^{0}\right] N_{t} \\
& F_{t+1} \equiv A_{t+1}-K_{t+1}-B_{t+1}
\end{aligned}
$$

Because the old (those born in period $t-2$ ) exhaust their lifetime savings at the end of period $t$, the total national stock of financial savings equals the 
stock of savings of the middle aged born in period $t-1$ plus the savings of the young born in period $t$.

Equilibrium for the world capital market is given in equation 24 . It says that the two capital stocks and the two stocks of public debt are willingly held.

$$
A_{t+1}+A_{t+1}^{*}=K_{t+1}+K_{t+1}^{*}+B_{t+1}+B_{t+1}^{*}
$$

If the self-financing constraint is binding in periods $t-1$ and $t$, the young do not save and gross interest earnings while middle aged are zero, so that

$$
\left(1+r_{t}-\theta_{t}\right)\left[w_{t-1} h_{t-1}^{0}-m_{t-1}-c_{t-1}^{0}\right] N_{t-1}=\left[w_{t} h_{t}^{0}-m_{t}-c_{t}^{0}\right] N_{t}=0 .
$$

Assuming that 25 holds for both countries for all $t \geq 0$, equilibrium for the world capital market is given by equation 26

$$
K_{t+1}+K_{t+1}^{*}+B_{t+1}+B_{t+1}^{*}=\left[w_{t} h_{t-1}^{1}-\tau_{t-1}^{1}-c_{t-1}^{1}\right] N_{t-1}+\left[w_{t}^{*} h_{t-1}^{* 1}-\tau_{t-1}^{* 1}-c_{t-1}^{* 1}\right] N_{t-1}^{*}
$$

\section{PERMANENT INTERNATIONAL PRO- DUCTIVITY GROWTH DIFFERENTIALS.}

Following Rebelo [1991], if we assume that the production function displays (asymptotically) constant returns to augmentable factors, then permanent positive rates of labor productivity growth are possible in this model. Since our model has two capital goods which cannot be transformed into each other costlessly and instantaneously, the growth rates of each factor and of output per capita are not constant over time in the general case. There are dynamics in transition to the long-run endogenous growth path.

Under constant returns to scale in the production of the single tradable good, long-run productivity growth rates can differ between countries even though there is perfect international mobility of financial capital, if the selffinancing constraint is binding on households in at least one of the countries. These differentials result from differences in the determinants of household saving, that is, differences in the intertemporal elasticity of substitution or rate of time preference or in fiscal policies that affect savings behavior. In 
Buiter and Kletzer [1991, 1993], similar permanent growth rate differentials arise under constant returns to augmentable factors in a model in which non-tradable household time, intrinsically valued as leisure, is necessary to augment the household's inherited stock of human capital.

With perfect international financial capital mobility, common technologies and constant returns to scale $(\alpha=1-\gamma)$, and without differential source-based capital income tax rates, both the rate of interest and the wage rate are equalized across borders. Equations 15 and 16 then imply that $k \equiv K / H$, the physical to human capital ratio, is the same for both countries. In this case, international differences in the growth rate of output per worker are only caused by differences in the growth rate of human capital per worker. The productivity of labor for the home country is given by

$$
\Pi_{t} \equiv Y_{t} /\left(N_{t}+N_{t-1}\right)=h_{t-1}^{1} k_{t}^{1-\alpha} \quad 17
$$

and the growth rate of output per worker for the home country, $\pi$, is given by

$$
\pi_{t} \equiv \frac{\Pi_{t+1}}{\Pi_{t}}-1
$$

In steady state 21 , the labor productivity growth rate differential is

$$
\pi-\pi^{*}=\frac{h_{t}^{1}}{h_{t-1}^{1}}-\frac{h_{t}^{* 1}}{h_{t-1}^{* 1}} .
$$

From equations 5 and 7 , we have that

$$
\frac{h_{t}^{1}}{h_{t-1}^{1}}=\delta\left[1+\xi\left(\frac{m_{t}+g_{t}}{\delta h_{t-1}^{1}}\right)\right]
$$

From the solutions for the household optimum, we see that, when human capital does not depreciate between generations in the absence of education $(\delta=1)$, steady-state per capita output growth rates are positive whenever educational expenditures are positive. Rewriting equation 26 , the capital market equilibrium condition when the self-financing constraint is binding in both countries, by expressing financial assets as ratios to human capital, we obtain

$$
k_{t+1}\left(1+\sigma_{t}^{*}\right)+b_{t+1}+\sigma_{t}^{*} b_{t+1}^{*}=\left[w_{t} h_{t-1}^{1}-c_{t-1}^{1}-\tau_{t-1}^{1}\right]\left[(2+n) h_{t}^{1}(1+n)\right]^{-1}
$$




$$
+\sigma_{t}^{*}\left[w_{t} h_{t-1}^{* 1}-c_{t-1}^{* 1}-\tau_{t-1}^{* 1}\right]\left[\left(2+n^{*}\right) h_{t}^{* 1}\left(1+n^{*}\right)\right]^{-1}
$$

where $b \equiv B / H, b^{*} \equiv B^{*} / H^{*}$ and $\sigma_{t}^{*} \equiv \frac{h_{i}^{-1} N_{0}^{*}\left(2+n^{*}\right)}{h_{i}^{1} N_{0}(2+n)}\left(\frac{1+n^{*}}{1+n}\right)^{t}$. The ratio of the foreign to the domestic stock of human capital, $\sigma^{*}$, is a convenient measure of the relative size of the foreign country.

Equation 31 suggest that there are two different kinds of steady state that might, for different values of the parameters, be approached by an equilibrium sequence for this model. In one of these steady states $\sigma^{*}$ or $\frac{1}{\sigma^{*}}$ equals zero. Along an equilibrium sequence converging to such a steady state, the long-run growth rates of the total stocks of national human capital are different between the two countries, so that the relative size of the country with the lower growth rate of human capital decreases steadily, that is, $\sigma^{*}$ or $\frac{1}{\sigma^{*}}$ approaches zero. Note that, since the ratio of human to non-human capital is constant in steady state, the share of the world physical capital stock too approaches zero for the country whose share of the world human capital stock goes to zero. In such a steady state the equilibrium values of global endogenous variables like the world interest rate are what they would be in the closed economy equilibrium of the economy whose share of world productive assets goes to unity. ${ }^{22}$.

In the other kind of steady state equilibrium, the long-run growth rates of human capital are the same, and $\sigma^{*}$ is positive and finite in the steady state. The growth rate of aggregate global human capital depends both on the rates of accumulation of human capital by the representative households of each generation in each country and on the population growth rates, which are allowed to differ across countries. In this case, each country will have a positive share of world financial and human wealth and of the world physical capital stock employed in it.

If the self-financing constraint is not binding in either country, then equality of the before-tax interest rates and of wage rates implies that the productivity growth rates are identical on every date under constant returns to scale with respect to augmentable factors. When the constraint is binding for one country, then equations 4,5 (holding with equality), 9, 10 and 13 imply that household tastes co-determine the productivity growth rate for that country. With common technologies, if the self-financing constraint is binding for at least one of the countries, then differences in household consumption behavior will cause steady-state productivity growth rates to differ.

As in Buiter and Kletzer [1993], we can study how differences in tastes 
or policies are related to steady-state growth rate differentials by analyzing the effects of small perturbations to the determinants of household asset accumulation around symmetric equilibria (that is, equilibria characterized by identical tastes, fiscal policies and initial conditions) on the productivity growth differential without considering the effects of such perturbations on $k_{t+1}$ and $k_{t+2}$. In this case, the effects of changes in policies or tastes on international productivity growth rate differences can be found by examining the effects of changes in a country's fiscal policies or taste parameters on that country's own productivity growth rate alone, at given values of $k_{t+1}$ and $k_{t+2}$. Because the analysis for this model parallels that of Buiter and Kletzer [1993] for a model with non-traded education time, we briefly summarize the results and refer the reader to that paper for further elaboration and justification.

Suppose that the self-financing constraint is binding for each country and that we increase the value of $\beta$, that is, the representative household in the home country becomes more patient. Using equation 10, an increase in $\beta$ holding $r_{t+1}, w_{t+1}$ and $h_{t}^{0}$ constant, raises the discounted marginal utility of investment in education for each value of $c_{t}^{1}$. This implies that $c_{t}^{0}$ falls and $m_{t}$ rises. The productivity growth differential, $\pi_{t}-\pi_{t}^{*}$, rises as well. For constant $r_{t+1}$ and $\theta_{t+1}$, the increase in $\beta$ leads to an increase in labor income and financial saving while middle-aged, so that $\frac{d c_{t}^{2}}{d \beta}>0$, but $\frac{d c_{t}^{1}}{d \beta}$ has an ambiguous sign.

Note that if the self-financing constraint is non-binding in equilibrium for both countries, then a small increase in $\beta$ for the home country will have no effect on the choice of educational inputs for constant post-tax interest rates. It will have an effect on the rate of physical capital accumulation for the world, and therefore, on the common international growth rate of productivity, but not on international productivity growth differentials.

Next, we consider how intergenerational redistribution using lump-sum taxes and transfers affects the productivity growth differential. The selffinancing constraints are assumed to be binding in both countries. Note that an increase in lump-sum taxes paid when middle-aged in period $t+1$ is equivalent to the same size increase in the period $t+1$ present value of lump-sum taxes paid when old in period $t+2$. This means that we only need to consider how increases in the net life-time lump-sum tax burden on generation $t, T_{t}=\tau_{t}^{1}+\left(1+r_{t+2}-\theta_{t+2}\right)^{-1} \tau_{t}^{2}$, affect human capital formation by that generation. The negative effect of an increase $T_{t}$ on life-time income reduces consumption while middle-aged and old. By reducing $c_{t}^{\mathbf{l}}$, when the 
self-financing constraint binds, the marginal utility of educational investment rises so that $m_{t}$ rises and $c_{t}^{o}$ falls for the home country. Therefore, an increase in $T_{t}$, the net life-time lump-sum tax burden on generation $t$, increases $\pi_{t}-\pi_{t}^{*}$, that is, it raises the growth rate of home country productivity between periods $t$ and $t+1$ relative to the growth rate of foreign productivity.

This tells us that an unfunded social security retirement scheme that favors the old at the expense of the young will tend to increase the rate of accumulation of human capital in the home country relative to the foreign country. Therefore, public sector deficit financing schemes that have the same intergenerational distributional impact as an unfunded social security retirement scheme (in our model e.g. transfer payments to the old or the middle-aged in period $t$, financed by borrowing, with the increased debt serviced through increased future taxes on those currently young), will also tend to increase the growth rate differential. Since redistribution from the young to the old in, say, the home country also reduces aggregate private saving in that country, such policies will also lead to financial crowding out of global physical capital accumulation. At a given global rate of interest rate, the growth rate of productivity in the foreign country would decline unambiguously. The effect on home country productivity growth would be ambiguous. Under mild restrictions, the world rate of interest would increase, however. Provided the substitution effect of a higher rate of return on saving dominates the income effect, this would tend to raise human capital formation in both countries, making the net effect on growth ambiguous for both countries.

An increase in public spending on education will, holding $m_{t}$ and the wage rate constant, reduce the marginal productivity of educational expenditures for the representative household. The self-financing constraints are again assumed to be binding in what follows. Holding constant interest rates, this will raise her income during middle age and lead to a rise in $c_{t}^{1}$ and $c_{t}^{2}$. This in turn requires $c_{t}^{0}$ to rise and $m_{t}$ to fall ${ }^{23}$. The net effect must be an increase in total (private plus public) education investment for the household and in the growth rate differential. Imposing a lump-sum tax when middle-aged so that the individual just pays the cost, inclusive of interest, of the public spending on her education will work to reduce the fall in $m_{t}$ leaving total education spending even higher.

An increase in $\theta_{t+2}$, the tax rate on saving during middle age for generation $t$, raises $c_{t}^{1}$ and $c_{t}^{0}$, provided the substitution effect of a higher rate of return on saving dominates the income effect. If the self-financing constraint is binding, then the rate of human capital formation is lowered in the home 
country. This will reduce the productivity growth rate differential. When the self-financing constraint is non-binding, then an increase $\theta_{t+2}$ also affects the economy through the behavior of the young born in period $t+1$. It raises the educational investment of generation $t+1$ since it reduces the return to financial saving while young.

\section{STEADY STATE GROWTH AND FISCAL POLICIES WITH SELF-FINANCED ED- UCATION.}

We can study the effects of fiscal policies on long-run factor accumulation and growth rates for an individual country more easily by restricting our attention to a single-country closed-economy model. It is also convenient to assume particular functional forms for household utility and the formation of human capital. The analysis can be extended to a two-country model in a straightforward but algebraically tedious manner.

We assume that utility is logarithmic. Generalizing to utility functions displaying constant intertemporal elasticities of substitution other than unity would not qualitatively change our key results (it would of course affect the magnitude or even the sign of the response of private saving to changes in the consumer's intertemporal terms of trade), but we save some notation. We also assume that the production function for human capital is given by

$$
h_{t}^{1}=\delta h_{t}^{0}\left[1+\left[\left(g_{t}+m_{t}\right) / \delta h_{t}^{0}\right]^{\eta}\right] \quad 0<\eta<1 .
$$

The first-order condition for the household's choice of $m_{t}$ becomes, when the non-negativity constraint on $m_{t}$ is not binding,

$$
c_{t}^{1}=\eta\left(\frac{g_{t}+m_{t}}{\delta h_{t}^{0}}\right)^{\eta-1} w_{t+1} \beta c_{t}^{0} .
$$

The first-order condition for substitution between consumption in middle age and when old

$$
c_{t}^{2}=\left(1+r_{t+2}-\theta_{t+2}\right) \beta c_{t}^{1}
$$

and the household's lifetime budget constraint when the self-financing constraint binds, yield 


$$
c_{t}^{1}=(1+\beta)^{-1}\left[w_{t+1} h_{t}^{1}-T_{t}\right]
$$

Substituting this last equation into 33 , we obtain

$$
(1+\beta)^{-1} \eta^{-1}\left[h_{t}^{1}-\frac{T_{t}}{w_{t+1}}\right]\left(\frac{g_{t}+m_{t}}{\delta h_{t}^{0}}\right)^{1-\eta}=\beta c_{t}^{0} .
$$

Imposing the assumed constraint on spending on education

$$
c_{t}^{0}+m_{t}=h_{t}^{0} w_{t}
$$

we obtain one of the equations that determine the equilibrium growth path of the economy:

$$
\frac{1}{\beta(1+\beta) \eta}\left[h_{t}^{1}-\frac{T_{t}}{w_{t+1}}\right]\left(\frac{g_{t}+m_{t}}{\delta h_{t}^{0}}\right)^{1-\eta}+m_{t}=h_{t}^{0} w_{t}
$$

By definition,

$$
K_{t+2} \equiv(2+n) N_{t+1} h_{t+1}^{1} k_{t+2}
$$

and

$$
B_{t+2} \equiv(2+n) N_{t+1} h_{t+1}^{1} b_{t+2}
$$

Saving per capita of the middle-aged (the generation born in period $t$ ) can be found from the necessary conditions for household optimization. In asset market equilibrium, savings in period $t+1$ by the middle-aged equals the capital stock used at time $t+2$ by the generation born at $t+1$ when middle-aged and by the generation born at $t+2$ while young plus the stock of public debt outstanding at the beginning of period $t+2$. In per capita terms, capital market equilibrium is given by

$$
\begin{aligned}
(1+n)(2+n)\left[b_{t+2}+k_{t+2}\right] & =\frac{1}{h_{t+1}^{1}}\left(\left(\frac{\beta}{1+\beta}\right)\left[w_{t+1} h_{t}^{1}-T_{t}\right]+\frac{\tau_{t}^{2}}{1+r_{t+2}-\theta_{t+2}}\right) \\
& =\frac{1}{h_{t+1}^{1}}\left(\begin{array}{c}
\left(\frac{\beta}{1+\beta}\right)\left[w_{t+1} h_{t}^{1}-\tau_{t}^{1}\right] \\
+\left(\frac{1}{1+\beta}\right) \frac{\tau_{t}^{2}}{1+r_{t+2}-\theta_{t+2}}
\end{array}\right)
\end{aligned}
$$

The dynamics for equilibrium of the economy under the condition that the self-financing constraint is always binding are given by equation 32 and 
equations 35 and 36 after substituting for the interest rate and wage rate from the production function.

When $\alpha=1-\gamma$, the wage rate and interest rate are given by

$$
\begin{gathered}
w_{t+1}=\alpha k_{t+1}^{1-\alpha} \\
r_{t+1}=(1-\alpha) k_{t+1}^{-\alpha}-\vartheta .
\end{gathered}
$$

The time paths for $T_{t}, g_{t}$ and $b_{t}$ are all given and satisfy the intertemporal budget identity for the government and its solvency constraint.

The government's budget identity can be written in intensive form as follows:

$$
b_{t+1} \equiv \frac{1}{\delta\left(1+x_{t}^{\eta}\right)}\left\{+\left(\frac{1}{2+n}\right)\left[\frac{g_{t}}{h_{t}^{0}}-\frac{\tau_{t-1}^{1}}{(1+n) h_{t}^{0}}-\frac{\left(\frac{1+r_{t}}{1+n}\right) b_{t}}{(1+n)^{2} h_{t}^{0}}-\theta_{t}\left(\frac{c_{t-2}^{2}+\tau_{t-2}^{2}}{1+r_{t}-\theta_{t}}\right) \frac{1}{(1+n)^{2} h_{t}^{0}}\right]\right\}
$$

In what follows, we restrict the analysis to balanced budget fiscal programs with a zero stock of public debt, that is, $b_{t}=0$ for all $t$. For reasons of space, we further limit consideration to the case where the distortionary tax on saving is zero $\left(\theta_{t}=0\right.$ for all $\left.t\right)$. The government budget identity therefore reduces to

$$
g_{t}=\frac{\tau_{t-1}^{1}}{1+n}+\frac{\tau_{t-2}^{2}}{(1+n)^{2}}
$$

We consider two financing policjes in particular. In the first, given in equation 37, lump-sum taxes and transfers redistribute resources between the old and the middle- aged, that is we consider a unfunded (pay-as-yougo) social security retirement scheme. ${ }^{24}$ In the second, given in equation 38 public spending on education is financed only through taxes on the middleaged, that is, $\tau_{t}^{2}=0$ for all $t$.

$$
\begin{aligned}
& \left\{\begin{array}{c}
\tau_{t}^{1}=-\frac{\tau_{t-1}^{2}}{1+n} \\
g_{t}=0
\end{array}\right\} \\
& \left\{\begin{array}{c}
g_{t}=\frac{\tau_{t-1}^{1}}{1+n}=\frac{T_{t-1}}{1+n} \\
\tau_{t}^{2}=0
\end{array}\right\}
\end{aligned}
$$

Rewriting these equations, we have 


$$
\begin{gathered}
h_{t+1}^{0}=\delta h_{t}^{0}\left[1+x_{t}^{\eta}\right] \\
\frac{\delta}{\eta(1+\beta) \beta} x_{t}^{1-\eta}\left[1+x_{t}^{\eta}\right]\left[1-\left(v_{t}^{1}+v_{t}^{2}\right)\right]+\delta x_{t}-\tilde{g}_{t}=\alpha k_{t}^{1-\alpha} \\
(1+n)(2+n) k_{t+1}\left[1+x_{t}^{\eta}\right] \delta=\left(\frac{\beta}{1+\beta}\left(1-v_{t-1}^{1}\right)+\frac{1}{1+\beta} v_{t-1}^{2}\right) \alpha k_{t}^{1-\alpha}
\end{gathered}
$$

and either

$$
\left\{\begin{array}{c}
v_{t-1}^{1} w_{t}+\frac{1}{1+n} v_{t-2}^{2}\left(1+r_{t}-\theta_{t}\right) w_{t-1} \frac{1}{\delta\left(1+x_{t-1}^{n}\right)}=0 \\
\tilde{g}_{t}=0
\end{array}\right\}
$$

or

$$
\left\{\begin{array}{c}
\tilde{g}_{t}=\frac{1}{1+n} v_{t-1}^{1} w_{t} \\
v_{t}^{2}=0
\end{array}\right\}
$$

where

$$
\begin{gathered}
\tilde{g}_{t} \equiv \frac{g_{t}}{h_{t}^{0}} \\
x_{t} \equiv \frac{g_{t}+m_{t}}{\delta h_{t}^{0}} \\
v_{t}^{1} \equiv \frac{\tau_{t}^{1}}{h_{t}^{1} w_{t+1}} \\
v_{t}^{2} \equiv \frac{\tau_{t}^{2}}{\left(1+r_{t+2}-\theta_{t+2}\right) h_{t}^{1} w_{t+1}}
\end{gathered}
$$

We can now examine local dynamics and the steady-state growth rates for this model. To find constant per capita human capital growth rate equilibria, we only consider equilibrium sequences for which $k_{t}=k_{t+1}$ and $x_{t}=x_{t+1}$. Fiscal policies need to be specified that support non-trivial long-run steady states.

For the first budgetary rule, given in 42 , we treat $v_{t}^{1}$ as exogenous and constant, $v_{t}^{1}=v^{1}$, with $v_{t-1}^{2}$ adjusting endogenously to satisfy the government budget constraint. For the second budgetary rule, given in 43 , we again treat 
$v_{t}^{1}$ as exogenous and constant, $v_{t}^{1}=v^{1}$, with $\tilde{g}_{t}$ adjusting endogenously to satisfy the government budget constraint.

Note that even though the actual taxes paid during middle age and old age are proportional to a household's human capital earnings when middleaged, the tax is taken as lump-sum by the household in making its decision concerning the accumulation of human capital when young.

\subsection{Redistribution towards the old.}

With the unfunded social security retirement scheme given in equation 42 , the model reduces to the following two equations.

$$
\begin{aligned}
& (1+n)(2+n) k_{t+1}\left[1+x_{t}^{\eta}\right] \delta \\
= & \frac{\beta}{1+\beta}\left\{1-\left[1+\frac{1}{\beta}\left(\frac{(1+n) \delta\left(1+x_{t}^{\eta}\right)}{1+(1-\alpha) k_{t+1}^{-\alpha}-\vartheta-\theta_{t+1}}\right)\left(\frac{k_{t+1}}{k_{t}}\right)^{1-\alpha}\right] v^{1}\right\} \alpha k_{t}^{1-\alpha} \\
& \quad \frac{\delta}{\eta(1+\beta) \beta} x_{t}^{1-\eta}\left[1+x_{t}^{\eta}\right]\left\{1-\left[1-\left(\frac{(1+n) \delta\left(1+x_{t+1}^{\eta}\right)}{1+(1-\alpha) k_{t+2}^{-\alpha}-\vartheta-\theta_{t+2}}\right)\left(\frac{k_{t+2}}{k_{t+1}}\right)^{1-\alpha}\right] v^{1}\right\} \\
+ & \delta x_{t}=\alpha k_{t}^{1-\alpha}
\end{aligned}
$$

Equation 48 can be solved for $x_{t}$ as a function of $k_{t}, k_{t+1}$ and $v^{1}$

$$
x_{t}=f\left(k_{t}, k_{t+1}, v^{1}\right)
$$

Using equation 50 to eliminate $x_{t}$ and $x_{t+1}$ from equation 49 yields a second-order non-linear difference equation in $k$. We have been unable to find transparent and intuitive restrictions on the structural parameters of the model that ensure local stability for this system.

In steady state the model reduces to

$$
\begin{aligned}
& (1+n)(2+n)\left[1+x^{\eta}\right] \delta \\
= & \frac{\beta}{1+\beta}\left\{1-\left[1+\frac{1}{\beta}\left(\frac{(1+n) \delta\left(1+x^{\eta}\right)}{1+(1-\alpha) k^{-\alpha}-\vartheta-\theta}\right)\right] v^{1}\right\} \alpha k^{-\alpha}
\end{aligned}
$$




$$
\begin{aligned}
& \frac{\delta}{\eta(1+\beta) \beta} x^{1-\eta}\left[1+x^{\eta}\right]\left\{1-\left[1-\left(\frac{(1+n) \delta\left(1+x^{\eta}\right)}{1+(1-\alpha) k^{-\alpha}-\vartheta-\theta}\right)\right] v^{1}\right\}+\delta x \\
= & \alpha k^{1-\alpha}
\end{aligned}
$$

The asymptotic growth rate of human capital and output per capita is given by

$$
\frac{h_{t+1}^{0}-h_{t}^{0}}{h_{t}^{0}}=\delta x^{\eta}+\delta-1
$$

so the effects of perturbations in fiscal policy or taste parameters on the long-run growth rate come only through the effects of these perturbations on $x$.

We will not inflict the algebraic details of the long-run comparative statics for this case on the reader, and just provide the intuition for our results. A set of sufficient conditions for the ratio of physical to human capital to go down in the long run when there is balanced-budget redistribution from the middle-aged to the old is (1) that the economy is dynamically efficient with the interest rate above the growth rate ${ }^{25}$ and (2) that the initial size of the intergenerational redistribution scheme is small ( $v^{1}$ is close to zero). Under these conditions, the negative impact effect on the saving rate of increased redistribution from the middle-aged to the old carries through in the long run as well.

The long-run effect on the growth rate of human capital is ambiguous even in this case, however. If the economy is dynamically efficient, increasing the size of an unfunded social security retirement scheme will, at given values of the wage and the stock of human capital, make people worse off: the biological rate of return offered by the unfunded scheme is dominated by the market rate of return. As people are worse off, they will reduce their consumption plans, including their consumption while young. This would permit $m$ to be increased. However, the negative effect on saving of the increase in the unfunded scheme will reduce the ratio of physical to human capital and thus the wage rate. This will tend to reduce the resources that can be allocated to $m$, when the borrowing constraint is binding. Since the effect of a lower value of $k$ on the wage rate will be larger the larger $1-\alpha$, the elasticity of output with respect to physical capital, a large value of $\alpha$ will make it more likely that the net effect of an increase in the scale of 
the unfunded social security retirement scheme will raise the growth rates of human capital and of labor productivity.

Note that this result is different from the one that would be obtained in the closed economy version of the model analyzed in Buiter and Kletzer [1991b, 1993]. There, human capital accumulation when young require the non-traded human capital endowment (efficiency units of time) and traded inputs. There are no borrowing constraints. The only alternative use of the endowment of human capital when young, however, is as leisure; the young cannot work and earn a wage. Any fiscal policy that makes a generation worse off will therefore, by reducing its consumption of leisure, unambiguously raise its rate of human capital formation.

The results of this subsection do not contradict the proposition that, in the two-country version of our model, redistribution from the middle-aged to the old in a country raises that country's growth rate relative to that in the other country. Because technologies are identical and the marginal products of physical capital are equalized in the two countries through perfect financial capital mobility, any reduction in the real wage affects both countries equally. The negative income effects from the intergenerational redistribution (if the economy is dynamically efficient) will therefore raise the rate of human capital formation in the country undergoing the policy change relative to that in the other country. The levels of the growth rates of human capital may go down in both countries, in one of them or in neither.

\subsection{Public spending on education financed with taxes on the middle-aged.}

In order to interpret the effect of an increase in public spending on the education of the young in our model, it is helpful to first consider the infeasible experiment of an increase in $\tilde{g}$ that does not have to be financed. Ignoring the government budget constraint and holding constant $v^{1}$ and $v^{2}$ ), the impacts of an increase in $\tilde{g}$ on the long-run growth rate and physical capital to human capital ratio are unambiguous (and unsurprising):

$$
\frac{d k}{d \tilde{g}}<0
$$

and

$$
\frac{d x}{d \tilde{g}}>0
$$


Returning to reality and requiring the increase in public eduction expenditure to be financed, according to the budgetary rule given in equation 43 , by taxing the middle-aged, the model reduces to the following two equations

$$
\begin{gathered}
\frac{\delta}{\eta(1+\beta) \beta} x_{t}^{1-\eta}\left[1+x_{t}^{\eta}\right]\left[1-v^{1}\right]+\delta x_{t}=\alpha k_{t}^{1-\alpha}\left(1+\frac{1}{1+n} v^{1}\right) \\
(1+n)(2+n) k_{t+1}\left[1+x_{t}^{\eta}\right] \delta=\frac{\beta}{1+\beta}\left(1-v^{1}\right) \alpha k_{t}^{1-\alpha}
\end{gathered}
$$

Equation 53 can be solved for $x_{t}$ as a function of $k_{t}$ and $v^{1}$. This solution for $x_{t}$ can then be substituted into equation 54 yielding a first-order nonlinear difference equation in $k$.

In the neighborhood of a steady state, the homogeneous part of the linearized equation of motion is given by

$$
k_{t+1}=\lambda k_{t}
$$

where

$$
\lambda=(1-\alpha)\left[1-\left(\frac{\frac{1-v^{1}}{(1+\beta) \beta}+\eta\left(\frac{x^{\eta}}{1+x^{\eta}}\right)}{1+\frac{\left(1-v^{1}\right)}{(1+\beta) \beta}\left[1+\left(\frac{1-\eta}{\eta}\right) x^{-\eta}\left(1+x^{\eta}\right)\right]}\right)\right],
$$

which is stable (positive but less than unity) for sufficiently small values of $\eta$.

From equation 55 it is easy to establish that

$$
\operatorname{sign} \frac{\partial \lambda}{\delta v^{1}}=\operatorname{sign}\left\{\eta\left(1-\frac{x^{\eta}}{1+x^{\eta}}\right)\right\}>0 \text { for } 0<\eta \leq 1
$$

Thus, the effect of an increase in public spending on education, financed with taxes on the middle-aged on the speed of convergence to the steady state is positive.

The equations defining steady values of $k$ and $x$ under this policy are given by

$$
\begin{gathered}
\frac{\delta}{\eta(1+\beta) \beta} x^{1-\eta}\left[1+x^{\eta}\right]\left[1-v^{1}\right]+\delta x=\alpha k^{1-\alpha}\left(1+\frac{1}{1+n} v^{1}\right) \\
(1+n)(2+n)\left[1+x^{\eta}\right] \delta=\alpha k^{-\alpha} \frac{\beta}{1+\beta}\left[1-v^{1}\right]
\end{gathered}
$$


The asymptotic growth rate of human capital and output per capita is again given by

$$
\frac{h_{t+1}^{0}-h_{t}^{0}}{h_{t}^{0}}=\delta x^{\eta}+\delta-1
$$

The following steady-state comparative static results obtain:

$$
\begin{gathered}
\frac{d k}{d v^{1}}<0 \\
\frac{d x}{d v^{1}}=\frac{\beta \alpha^{2} k^{-(1+\alpha)}}{(1+\beta) \tilde{D}}\left[-\delta x+\left((2 \alpha-1)\left(1+\frac{1}{1+n} v^{1}\right)+\frac{\alpha\left(1-v^{1}\right)}{1+n}\right) k^{1-\alpha}\right]
\end{gathered}
$$

An increase in the magnitude of the life-time lump-sum tax burden (relative to labor income) paid by the middle-aged has an unambiguously negative effect on the ratio of physical to human capital. The increase in public spending per se will raise private consumption and thus reduce physical capital formation. It will also reduce private expenditure on education but less than one-for one, leading to a net increase in $x$. Financing the expenditure by taxing the middle-aged will further reduce the saving rate of the economy. The effect of the taxes on the rate of accumulation of human capital and labor productivity growth in the long-run is ambiguous. At given prices and endowments, the tax increase makes people worse off, leading to a reduction in lifetime consumption, including a reduction in consumption when young. The resources thus freed get channelled into education. However, the reduction in the ratio of physical to human capital also lowers the wage rate, reducing the total resources available for consumption while young and private education expenditure. This effect is stronger the larger is $1-\alpha$, the elasticity of output with respect to physical capital. The net result is ambiguous, as shown in equation 58 . The sign of $\frac{d x}{d v^{1}}$ is positive only if the elasticity of output with respect to physical capital, $1-\alpha$, is so small that $2 \alpha-1$ is positive. The determinant of the matrix of coefficients obtained by total differentiation of equations 56 and $57, \tilde{D}$, is unambiguously positive. 


\section{DECREASING RETURNS AND CONVER- GENCE.}

In this section, we return to the two-country model and consider the case where the only steady state the economy can converge to is a stationary state, that is, a steady state with a zero growth rate of productivity. We therefore replace the assumption that goods production takes place under constant returns to augmentable factors by the assumption that goods production takes place under conditions of decreasing returns to augmentable factors: $\alpha+\gamma<1$. Under our assumption that there are no international externalities generated by human capital formation ${ }^{26}$, international differences in tastes and fiscal policies will now lead to different levels, rather than grow th rates, of output per capita and labor productivity in the steady state when the self-financing constraint is binding in at least one country. The rate of convergence to the stationary state will also differ across countries with different taste parameters, fiscal policies or initial conditions. For notational simplicity we also assume in what follows that the growth rates of population and labor force are zero, that is, $n=n^{*}=0$. We choose units for measuring population and labor force such that $N=N^{*}=\frac{1}{2} \cdot{ }^{27}$

If the self-financing constraint is non-binding on households in both countries and there are constant returns to augmentable factors, perfect international financial capital mobility and common technologies for augmenting human and physical capital stocks, then (assuming no distortionary sourcebased taxes on capital income) the growth rates of human capital are identical in every period, and there never is an international productivity growth differential. Even in this case, productivity levels (the levels of output per worker) can still differ. This is clear from $\Pi_{t}=h_{t}^{0} k_{t}^{1-\alpha}$ and the fact that the level of human capital per capita need not be equal across countries. Human capital is non-traded and the implicit domestic technological transformation locus between human and physical capital is concave towards the origin.

With decreasing returns to augmentable factors, differences in tastes or policies that influence the intertemporal decisions of households are still not sufficient to generate different rates of convergence when the self-financing constraints are non-binding for all households. However, there will be different rates of convergence and differences in the transitional rates of growth of human capital per capita if the initial endowments of human capital differ across borders. This is because human capital is non-traded and cannot 
be transformed costlessly into physical capital, unlike the model of Barro, Mankiw and Sala-i-Martin [1992], which has a linear technological transformation locus between physical and human capital.

It is easy to see that convergence is not immediate in this case. If the selffinancing constraint is non-binding and financial (equivalently here, physical) capital is perfectly mobile, equations 59,60 and 61 hold. For simplicity, residence-based saving taxes are ignored in what follows. The logarithmic utility function and exponential human capital accumulation specifications of the previous sections are also retained. We assume that the government budget is balanced continuously and that public spending on education is financed through taxes on the middle-aged only.

$$
\begin{gathered}
\eta x_{t}^{\eta-1}=\frac{1+r_{t+1}}{w_{t+1}} \\
r_{t+1}=(1-\alpha) k_{t+1}^{\gamma-1}\left(h_{t+1}^{0}\right)^{\alpha+\gamma-1}-\vartheta=(1-\alpha) k_{t+1}^{* \gamma-1}\left(h_{t+1}^{* 0}\right)^{\alpha+\gamma-1}-\vartheta
\end{gathered}
$$

Note that wage rates are given by

$$
w_{t+1}=\alpha k_{t+1}^{\gamma}\left(h_{t+1}^{0}\right)^{\alpha+\gamma-1} \text { and } w_{t+1}^{*}=\alpha k_{t+1}^{* \gamma}\left(h_{t+1}^{* 0}\right)^{\alpha+\gamma-1},
$$

and recall that

$$
\frac{h_{t+1}^{0}-h_{t}^{0}}{h_{t}^{0}}=\delta x_{t}^{\eta}+\delta-1
$$

and

$$
\frac{h_{t+1}^{* 0}-h_{t}^{* 0}}{h_{t}^{* 0}}=\delta x_{t}^{* \eta}+\delta-1
$$

If the endowments of human capital in period $t$ differ, then the physical capital to human capital ratio, $k_{t+1}$ and $k_{t+1}^{*}$, for period $t+1$ will be different in the home and foreign country given 60 when $\alpha+\gamma<1 . k_{t+1}$ and $h_{t+1}^{0}$ will be inversely related, and, therefore, the rate of human capital accumulation will be higher in the country with the lower initial level of human capital. Differences in household tastes play no role in determining these differences in rates of convergence to a common steady state in levels of human capital and output per capita. Lump-sum fiscal policies and public spending on the private inputs to educations do not either. 
With the self-financing constraint binding, our model implies more than these "engineering" kind of transition dynamics. For the logarithmic utility example, equations 33,34 and 35 still hold for each household of the home country with analogous counterparts for foreign households. The rate of human capital accumulation in the home country is now determined by equation 62 :

$$
\frac{\delta}{\eta(1+\beta) \beta} x_{t}^{1-\eta}\left[1+x_{t}^{\eta}\right]\left[1-v^{1}\right]+\delta x_{t}=\alpha k_{t}^{\gamma}\left(h_{t}^{0}\right)^{\alpha+\gamma-1}\left(1+v^{1}\right)
$$

With perfect financial capital mobility, the country with the lower endowment of human capital will have a higher value of $k$. Both will make for a higher wage and thus a higher rate of private investment in education. This implies that convergence rates will differ and that this differential will be affected by changes in lump-sum fiscal policies or public spending on education. While we have dropped the extra policy parameters here, distortionary residence-based asset income taxes will also affect convergence rates.

To understand how fiscal policy affects long-run levels of human capital and convergence rates, we revert to a closed-economy model for analytical simplicity.

For given initial values of the two capital stocks, the behavior over time of physical and human capital accumulation in the home country are now jointly determined with $x$ by equations 62,63 and 64 , reproduced below.

$$
\begin{gathered}
2 k_{t+1}\left[1+x_{t}^{\eta}\right] \delta=\left(\frac{\beta}{1+\beta}\right)\left[1-v^{1}\right] \alpha k_{t}^{\gamma}\left(h_{t}^{0}\right)^{\alpha+\gamma-1} \\
h_{t+1}^{0}=h_{t}^{0} \delta\left(1+x_{t}^{\eta}\right) .
\end{gathered}
$$

Solving equation 62 for $x_{t}$ as a function of $k_{t}, h_{t}^{0}$ and $v^{1}$ and substituting the resulting equation into equations 63 and 64 we get a non-linear, twodimensional system of first-order difference equations in $k$ and $h^{0}$. Linearizing this system at a steady state produces the linearized homogeneous equation system given in 65 .

$$
\begin{gathered}
{\left[\begin{array}{l}
k_{t+1} \\
h_{t+1}^{0}
\end{array}\right] \approx\left[\begin{array}{ll}
a_{11} & a_{12} \\
a_{21} & a_{22}
\end{array}\right]\left[\begin{array}{l}
k_{t} \\
h_{t}^{0}
\end{array}\right]} \\
a_{11}=\left[\frac{1}{2}\left(\frac{\beta}{1+\beta}\right)\left(1-v^{1}\right)-\Omega^{-1} \eta\left(1+v^{1}\right)\left(\frac{1-\delta}{\delta}\right)^{\frac{\eta-1}{\eta}} k\right] \alpha \gamma\left(h^{0}\right)^{\alpha+\gamma-1} k^{\gamma-1}
\end{gathered}
$$




$$
\begin{gathered}
a_{12}=\left[\begin{array}{c}
\frac{1}{2}\left(\frac{\beta}{1+\beta}\right)\left(1-v^{1}\right) \\
-\Omega^{-1} \eta\left(1+v^{1}\right)\left(\frac{1-\delta}{\delta}\right)^{\frac{\eta-1}{\eta}} k
\end{array}\right] \alpha(\alpha+\gamma-1)\left(h^{0}\right)^{\alpha+\gamma-2} k^{\gamma} \\
a_{21}=\Omega^{-1} \eta \alpha \gamma\left(1+v^{1}\right)\left(\frac{1-\delta}{\delta}\right)^{\frac{\eta-1}{\eta}}\left(h^{0}\right)^{\alpha+\gamma} k^{\gamma-1}>0 \\
a_{22}=1+\Omega^{-1} \eta \alpha(\alpha+\gamma-1)\left(1+v^{1}\right)\left(\frac{1-\delta}{\delta}\right)^{\frac{\eta-1}{\eta}}\left(h^{0}\right)^{\alpha+\gamma-1} k^{\gamma}
\end{gathered}
$$

where

$$
\Omega=1+\frac{\left(1-v^{1}\right)}{(1+\beta) \beta}\left[1+\left(\frac{1-\eta}{\eta}\right)\left(\frac{1}{1-\delta}\right)\right]>1
$$

Necessary and sufficient conditions for the system given in equation 65 to have two stable characteristic roots are

$$
1-a_{11}>0
$$

and

$$
\left|\begin{array}{ll}
1-a_{11} & -a_{12} \\
-a_{21} & 1-a_{22}
\end{array}\right|>0
$$

Condition 72 is clearly satisfied, as the relevant determinant is equal to $\Omega^{-1} \eta \alpha(1-\alpha-\gamma)\left(1+v^{1}\right)\left(\frac{1-\delta}{\delta}\right)^{\frac{\eta-1}{\eta}}\left(h^{0}\right)^{\alpha+\gamma-1} k^{\gamma}$, which is positive. Condition 71 will be satisfied if $\beta$ is sufficiently small or if $v^{1}$ is sufficiently large, that is when the parameters of the model discourage saving.

Finally, we consider how an increase in life-time lump-sum taxes paid by the middle-aged which is used to finance an increase in public spending on education affects the steady state. In a steady state with a positive level of $h^{0}, x$ is given by the following equation.

$$
x^{\eta}=\frac{1-\delta}{\delta}
$$

Equation 74 and 75 are the remaining stationary state conditions. 


$$
\begin{gathered}
2 k^{1-\gamma}=\frac{\beta}{1+\beta}\left(1-v^{1}\right) \alpha\left(h^{0}\right)^{\alpha+\gamma-1} \\
\frac{1}{\eta(1+\beta) \beta}\left(\frac{1-\delta}{\delta}\right)^{\frac{1-\eta}{\eta}}\left[1-v^{1}\right]+\delta\left(\frac{1-\delta}{\delta}\right)^{\frac{1}{\eta}}=\alpha k^{\gamma}\left(h^{0}\right)^{\alpha+\gamma-1}\left(1+v^{1}\right)
\end{gathered}
$$

These last two equations can be solved for the stationary state values of $k$ and $h^{0}$. Given our assumptions, there are positive solutions for both $k$ and $h$. Differentiation of 74 and 75 yields the following results, that parallel those in the constant returns to augmentable factors case:

$$
\begin{gathered}
\frac{d k}{d v}=-\frac{\beta}{2(1+\beta)}\left(\frac{1}{1+v^{1}}\right)\left[\left(\frac{\left(1-v^{1)}\right.}{\eta(1+\beta) \beta}\right)\left(\frac{1-\delta}{\delta}\right)^{\frac{1-\eta}{\eta}}+2 \alpha k^{\gamma}\left(h^{0}\right)^{\alpha+\gamma-1}\right]<0 \\
\frac{d h^{0}}{d v}=\frac{-h^{0}}{1-\alpha-\gamma}\left[\gamma-\left(\frac{1-\gamma}{1+v^{1}}\right)\left(1+\frac{\left(1+v^{1}\right) \eta(1+\beta) \beta}{1-v^{1}+(1-\delta) \eta(1+\beta) \beta}\right)\right]
\end{gathered}
$$

The steady-state physical to human capital ratio declines, but the sign of steady human capital per household is ambiguous. For a large value of $\gamma$, the elasticity of output with respect to physical capital, an increase in lump-sum taxes on the middle-aged used to finance an increase in public spending on education, causes $h^{0}$ to fall, but if $\gamma$ is small, then the steady-state human capital endowment rises. This is because the increase in $\tau^{1}$ leads to a decrease in $c^{0}$ and a fall in the wage rate for given $h^{0}$. Since the steady-state ratio of $m$ to $h$ is fixed, $m$ can fall if the second effect is stronger than the first.

\section{CONCLUSION.}

This paper extends the analysis of the effects of fiscal policies in endogenous growth models under the assumption of perfect international financial capital mobility by considering the role of domestic capital market imperfections. Capital markets are incomplete because young households cannot borrow against the future returns to human capital to finance the educational expenditures necessary for augmenting their endowments of human capital. 
We began by extending our own previous analysis of cross-country growth rate differentials when the technology for producing final goods displays constant returns to scale and to augmentable factors. As in our earlier work, a lump-sum fiscal policy that redistributes in favor of the currently old and away from the middle-aged results in an increase in the rate of growth for the home country relative to the foreign country. We also analyzed the effects of distortionary residence-based taxes on the returns to financial savings and of public spending on educational inputs for individuals.

The rest of the paper investigates, in a closed economy setting, the financial crowding out or crowding in of private sector physical and human capital accumulation by lump-sum fiscal intergenerational redistribution and public spending on eduction. Our results here qualify the result obtained in our earlier work, that the level of the rate of growth of human capital unambiguously increases in the country implementing the redistribution towards the old. For obvious life-cycle reasons, such a policy reduces financial saving and thus the rate of physical capital formation and the long-run ratio of physical to human capital. This reduces the real wage and with it the resources available to the borrowing-constrained young for consumption and investment in human capital formation. The policy will therefore only raises investment in human capital if the elasticity of output with respect to physical capital is not too high.

An increase in public spending on education financed by taxing the middleaged will reduce the steady-state ratio of physical to human capital and has an ambiguous effect on the growth rate of human capital although, holding constant the increase in the tax on the middle-aged, the policy is more likely to raise the growth rate than would be the case of the increase in taxes on the middle-aged were to be paid as increased transfers to the old. An increase in public spending will tend to raise the rate of convergence to the steady state in the endogenous growth model.

When we consider the possibility of convergence to an endogenously determined steady state in the presence of decreasing returns to scale in augmentable factors of production, permanent unfunded social security schemes that favor the old reduce the steady-state capital stock and raise the level of human capital per capita as long as the physical capital share is not too large. An increase in public spending on education financed by taxing the middleaged will reduce the steady-state ratio of physical to human capital and has a positive effect on the level of human capital per capita if the elasticity of output with respect to physical capital is not too large. 
Our balanced-budget results can easily be extended to scenarios including non-zero levels of public sector deficits and debt. For instance, a higher public debt burden, to the extent that it represents a net intergenerational redistribution toward the old ${ }^{28}$, will reduce conventionally defined financial saving but can lead to a rise in human capital accumulation when the ability of young households to substitute human wealth for financial wealth in their portfolios is restricted.

\section{References}

[1] Alogoskoufis, George S. and Frederick van der Ploeg [1991], "On Budgetary Policies, Growth and External Deficits in an Interdependent World", Journal of the Japanese and International Economies, 5, pp. 305-324.

[2] Azariadis, Costas and Allan Drazen [1990], "Threshold Externalities in Economic Development", Quarterly Journal of Economics, Vol 105, May, pp. 501-526.

[3] Barro, Robert J. [1991], "Economic growth in a cross section of countries", Quarterly Journal of Economics, CVI, pp. 407-445.

[4] Barro, Robert J. and Xavier Sala $i$ Martin [1992], "Public finance in models of economic growth", Review of Economic Studies, 59, pp 645661.

[5] Barro, Robert J. and Xavier Sala $i$ Martin [1991], "Convergence across states and regions", Brookings Papers on Economic Activity, 1, pp 107158.

[6] Barro, Robert J. and Xavier Sala $i$ Martin [1992], "Convergence," Journal of Political Economy, 100, pp. 223-251.

[7] Barro, Robert J., N. Gregory Mankiw and Xavier Sala $i$ Martin [1992], "Capital Mobility in Neoclassical Models of Growth," mimeo, Harvard University, June.

[8] Becker, Gary S. [1975], Human Capital: A Theoretical and Empirical Analysis with Special Reference to Education, Second Edition, University of Chicago Press, Chicago. 
[9] Behrman, Jere R., Lori G. Kletzer, Michael S. McPherson and Morton O. Schapiro [1992], "The College Investment Decision: Direct and Indirect Effects of Family Background on the Choice of Postsecondary Enrollment and Quality," Williams College, mimeo, April.

[10] Bernard, Andrew B. and Steven N. Durlauf [1994], "Interpreting Tests of the Convergence Hypothesis," NBER Technical Working Paper No. 159, June.

[11] Bernheim, B. and K. Bagwell [1988], "Is everything neutral?", Journal of Political Economy, 96, April, pp. 308-338.

[12] Borjas, George J. [1992], "Ethnic capital and intergenerational mobility", Quarterly Journal of Economics, Vol. 107, February, pp. 123-150.

[13] Buiter, Willem H. [1981], "Time preference and international lending and borrowing in an overlapping-generations model", Journal of Political Economy, 89, August, pp. 769-97.

[14] - [1989], Budgetary policy, international and intertemporal trade in the global economy, Amsterdam, North-Holland.

[15] - and Kenneth M. Kletzer [1990], "Fiscal policy, interdependence and efficiency", NBER Working Paper No. 3328, April.

[16] ____ and [1991a], "The welfare economics of cooperative and non-cooperative fiscal policy", Journal of Economic Dynamics and Control, 15, pp. 215-244.

[17] - and [1991b], "Persistent Differences in National Productivity Growth Rates with a Common Technology and Free Capital Mobility; the roles of public debt, capital taxation and policy towards human capital formation", Journal of the Japanese and International Economies, 5, pp. 325-353.

[18] _._____ and ______ [1992], "Government Solvency, Ponzi Finance and the Redundancy and Usefulness of Public Debt", Yale University, Economic Growth Center Discussion Paper No. 659, April. 
[19] [1992], "Permanent International Productivity Growth Differentials in an Integrated Global Economy," NBER Working Paper No. 4220, November.

[20] - and [1993], "Permanent International Productivity Growth Differentials in an Integrated Global Economy," The Scandinavian Journal of Economics, 95, pp. 467-493.

[21] Cameron, Stephen V. and James J. Heckman [1992], "The Dynamics of Educational Attainment For Blacks, Whites and Hispanics," University of Chicago, mimeo, April.

[22] De Gregorio, Jose and Se-Jik Kim [1994], "Credit Markets in a Model of Heterogeneous Agents: Education, Distribution and Growth," mimeo, International Monetary Fund, February.

[23] Diamond, Peter A. [1965], "National Debt in a Neo-classical Growth Model",American Economic Review, 55, pp. 1126-1150.

[24] Edwards, Sebastian [1989], "Openness, outward orientation, trade liberalization and economic performance in developing countries", NBER Working Paper No. 2908, March.

[25] Feenstra, Robert [1990], Trade and Uneven Growth", NBER Working Paper No. 3276, March.

[26] Frenkel, Jacob A. and Assaf Razin [1987], Fiscal Policies and the World Economy, MIT Press, Cambridge Massachusetts.

[27] Grossman, Gene M. and Elhanan Helpman [1989], "Product development and international trade", Journal of Political Economy, 97, pp. 1261-1283.

[28] - and [1990], "Comparative advantage and longrun growth", American Economic Review, 80, pp. 796-815.

[29] and [1991], Innovation and Growth in the Global Economy, MIT Press, Cambridge, Massachusetts.

[30] Hart, Oliver D. and John Moore [1991], "A theory of debt based on the inalienability of human capital," NBER Working Paper No. 3906. 
[31] Jones, Larry E., Rodolfo Manuelli and Peter E. Rossi [1993], "Optimal taxation in models of endogenous growth," Journal of Political Economy, 101, June, pp. 485-517.

[32] Jones, Larry E. and Rodolfo Manuelli [1990], "Finite lifetimes and growth" , NBER Working Paper No. 3469.

[33] King, Robert G. and Sergio Robelo [1990], "Public policy and economic growth: developing neoclassical implications", Journal of Political Economy, 98, pp. S126-S150.

[34] Lucas, Robert E. Jr. [1988],"On the mechanics of economic development", Journal of Monetary Economics, 22, pp. 3-42.

[35] Milesi-Ferretti, Gian Maria and Nouriel Roubini [1993], "Optimal taxation of human and physical capital in endogenous growth models," mimeo, Yale University, December.

[36] Purvis, Douglas D. [1975], "Human capital, the financial portfolio, and the crowding-out effect," Queen's University Discussion Paper.

[37] [1985], "Innis lecture: public sector deficits, international capital movements and the domestic economy: the medium term is the message," Canadian Journal of Economics, 18, pp. 723-742.

[38] Quah, Danny and James E. Rauch [1990], "Openness and the Rate of Economic Growth", Mimeo, October.

[39] Razin, Assaf [1972], "Investment in Human Capital and Economic Growth",Metroeconomica, 24, May-August, pp. 101-116

[40] Rebelo, Sergio [1991], "Long run policy analysis and long run growth," Journal of Political Economy, 99, pp. 500-521.

[41] Romer, Paul M. [1986], "Increasing returns and long-run growth", Journal of Political Economy, 94, October, pp. 1002-1037.

[42] - [1987], "Growth based on increasing returns due to specialization", American Economic Review, Papers and Proceedings,77, May, pp. 56-62. 
[43] [1989], "Human capital and growth: theory and evidence", NBER Working Paper No. 3173 , November.

[44] [1990a], "Capital, Labor, and Productivity", Brookings Papers on Economic Activity, Microeconomics, pp. 337367.

[45] _-_._ [1990b], "Endogenous technical change",

Journal of Political Economy, Vol. 98, No. 5, Pt. 2, pp. s71-S102.

[46] - [1990c], "Are nonconvexities important for understanding growth?" NBER Working Paper No. 3271, February.

[47] Samuelson, Paul A. [1958], "An Exact Consumption-Loan Model of Interest, with or without the Social Contrivance of Money", Journal of Political Economy, 66, pp. 467-482.

[48] Uzawa, Hirofumi [1965], "Optimum technical change in an aggregate model of economic growth", International Economic Review, 6, pp. 1831.

[49] Young, Alwyn [1991], "Learning by doing and the dynamic effects of international trade, Quarterly Journal of Economics, 


\section{Notes}

${ }^{1}$ See, for example, Romer [1986, 1987, 1989, 1990a, b, c], Lucas [1988], Grossman and Helpman [1989, 1990, 1991], Young [1991], Azariadis and Drazen [1990], Feenstra [1990] and Quah and Rauch [1990].

${ }^{2}$ Lucas [1988, pp.14-17] recognizes and emphasizes the importance of factor mobility assumptions for the predictions of neo-classical growth theory. Barro [1991] and Barro and Sala-i-Martin [1991], for example, assume common technologies and industrial structures but that there are barriers to factor mobility across regions or states. Buiter and Kletzer [1991, 1993] argue that factor mobility is just as important for endogenous growth theory with constant or increasing returns.

${ }^{3}$ One example is Edwards [1989], where is assumed that countries do not have access to a common global technology. Instead, backward nations can gradually catch up to the higher external level of technology. Another example is due to Barro, Mankiw and Sala-i-Martin [1992], where there is heterogeneous capital in a neoclassical growth model. They compare the dynamics under the assumptions that human capital is internationally tradable and that it is not. Note that the concept of restricted trading opportunities contains that of incomplete markets. but is not identical to it. It also includes the incomplete market participation found in all OLG models and the technological restrictions on trade underlying open economy models with traded and non-traded goods sectors.

${ }^{4}$ Our model is based on the two-country exogenous growth OLG models of Buiter [1981] and Buiter and Kletzer [1990, 1991a]. A very simple two-country endogenous growth model with the SamuelsonDiamond OLG household sector is developed in Buiter and Kletzer [1991b]. Two-country exogenous and endogenous growth models with the Yaari-Blanchard OLG household sector are studied by Buiter [1989] and Frenkel and Razin [1987], and by Alogoskoufis and van der Ploeg [1991], respectively. Closed economy endogenous growth models with a Samuelson-Diamond OLG household sector have been developed by Azariadis and Drazen [1990] and by Jones and Manuelli [1990b].

${ }^{5}$ We maintain the assumption of the earlier paper that physical capital accumulation requires only traded inputs. 
${ }^{6}$ Whether or not growth rates converge across countries is still a controversial issue in the empirical literature on economic growth. See, for example, Barro and Sala-i-Martin [1992] and Bernard and Durlauf [1994] for discussions. Given this, we discuss both the convergent and non-convergent cases for our model.

${ }^{7}$ Other papers analyzing the consequences of the use of distortionary taxes in (closed) endogenous growth models with a representative agent household sector are King and Rebelo [1990], Rebelo [1991], Jones, Manuelli and Rossi [1993] and Milesi-Ferretti and Roubini [1993]. Barro and Sala-i-Martin [1992] consider both distortionary taxation and productive public spending. Our earlier papers, Buiter and Kletzer [1991, 1993] both analyze distortionary taxes on saving and subsidies to borrowing and public spending on private inputs to the education process in a similar overlapping generations model.

${ }^{8}$ The point that self-financing of tradable inputs to human capital formation can serve the same role as non-tradability of an essential input is made in our earlier working paper (Buiter and Kletzer [1992]). For the sake of shortening, this material was removed from Buiter and Kletzer [1993] and finds a suitable vehicle here.

${ }^{9}$ Assuming imperfect substitutability between $m$ and $g$ would add to the algebra without qualitatively changing the effects of $g$ on human capital formation and private financial saving. It would create a role for government in human capital formation that is too straightforward to merit analysis.

${ }^{10}$ Note that our human capital formation externality will not be fully internalized even if one assumed universal operative intergenerational gift motives unless, through vigorous intermarriage as noted by Bernheim and Bagwell [1988], all of society effectively constitutes one big happy family. This is because the externality in this model extends across families or dymasties as well as generations.

${ }^{11}$ Another related formulation is given by Azariadis and Drazen [1990]. They assume that the young can devote part of their endowment of time to human capital formation. Buiter and Kletzer [1991 and 1993] add tradable inputs to the production process for human capital in a special functional form of the specificition proposed by Azariadis and Drazen. The focus of each of our papers is very different from that of Azariadis 
and Drazen. The study the role of nonconvexities in the production and accumulation of human capital as a source of multiple locally stable stationary equilibria in a closed economy model.

${ }^{12}$ Education as fun is not included in the model.

${ }^{13}$ Hart and Moore [1991] propose a theory of credit market imperfections based on the removal of human capital from the pool of potential loan collateral.

${ }^{14} u($.$) is increasing, strictly quasi-concave, twice-continuously dif-$ ferentiable and satisfies the Inada conditions $\lim _{x \rightarrow \infty} u^{\prime}(x)=$ $1 / \lim _{x \rightarrow 0} u^{\prime}(x)=0 ; \beta>0$.

${ }^{15}$ Since a unit of capital is really a bundle of a unit of physical capital and a claim to $\frac{1}{K}$ times the pure profits $[1-(\alpha+\gamma)] Y$ that period, capital earns the sum of its marginal product $\gamma H_{t}^{\alpha} K_{t}^{\gamma-1}-\vartheta$ and the pure profit rate $\frac{[1-(\alpha+\gamma)] Y_{t}}{K_{t}}$.

${ }^{16}$ See Buiter and Kletzer [1992] for an analysis of the conditions under which the conventional government solvency constraint (18) is implied by more robust notions of feasibility of government tax, spending and financing plans.

$$
{ }^{17} \Pi_{t} \equiv \frac{H_{t}^{\alpha} K_{t}^{1-\alpha}}{N_{t}+N_{t-1}}=\frac{H_{i}}{N_{t}+N_{t-1}} k_{t}^{1-\alpha} \text { and } H_{t}=N_{t} h_{t}^{0}+N_{t-1} h_{t-1}^{1}=\left(N_{t}+\right.
$$
$\left.N_{t-1}\right) h_{t-1}^{1}$ (using equation 7)

${ }^{18} \Pi_{t} \equiv \frac{H_{t}^{\alpha} K_{t}^{1-\alpha}}{N_{t}+N_{t-1}}=\frac{H_{i}}{N_{t}+N_{t-1}} k_{t}^{1-\alpha}$ and $H_{t}=N_{t} h_{t}^{0}+N_{t-1} h_{t-1}^{1}=\left(N_{t}+\right.$ $\left.N_{t-1}\right) h_{t-1}^{1}$ (using equation 7)

${ }^{19} \Pi_{t} \equiv \frac{H_{t}^{\alpha} K_{t}^{1-\alpha}}{N_{t}+N_{t-1}}=\frac{H_{i}}{N_{t}+N_{t-1}} k_{t}^{1-\alpha}$ and $H_{t}=N_{t} h_{t}^{0}+N_{t-1} h_{t-1}^{1}=\left(N_{t}+\right.$ $\left.N_{t-1}\right) h_{t-1}^{1}$ (using equation 7 )

${ }^{20} \Pi_{t} \equiv \frac{H_{t}^{a} K_{t}^{1-\alpha}}{N_{t}+N_{t-1}}=\frac{H_{i}}{N_{t}+N_{t-1}} k_{t}^{1-\alpha}$ and $H_{t}=N_{t} h_{t}^{0}+N_{t-1} h_{t-1}^{1}=\left(N_{t}+\right.$ $\left.N_{t-1}\right) h_{t-1}^{1}$ (using equation 7)

${ }^{21}$ For a steady state to exist, preferences must be homothetic.

${ }^{22}$ If governments issue debt, this statement needs to be qualified somewhat. Even if, say, $\sigma_{t}^{*}$ goes to zero, it is possible that $\sigma_{t}^{*} b_{t+1}^{*}$ goes to infinity without the foreign country's government solvency constraint being violated (that is, with the growth rate of the foreign public debt always below the rate of interest). For reasons of space, we only refer in 
the body of the paper to the case where $\sigma_{t}^{*} b_{t+1}^{*}$ goes to zero whenever $\sigma_{t}^{*}$ goes to zero.

${ }^{23}$ We assume that the non-negativity constraint on $m_{t}$ is non-binding.

${ }^{24}$ The restriction, in this section of the paper, to balanced budget lump-sum fiscal policies with a zero stock of public debt, is not necessarily very severe. Extending the standard debt irrelevance result for OLG models, unfunded social security schemes involving only the middleaged and old support the full range of competitive equilibria that can be achieved by including public debt for this model if the self-financing constraint is binding. If the government ld also levy lump-sum taxes on the young, there would not be any loss of generality in restricting ourselves to balanced budget redistribution schemes even when the selffinancing constraint is non-binding. We do not expect that the constraint is going to be binding, even just in the steady state, for all feasible balanced budget redistribution schemes involving only the middle-aged and old. Buiter and Kletzer [1992] discuss the extension of the irrelevance of debt results to other cases when lump-taxes are restricted.

${ }^{25}$ That is, $\frac{(1+n) \delta\left(1+x^{n}\right)}{1+r-\theta} \leq 1$.

${ }^{26}$ Our assumption that the external effects from investment in human capital by the previous generation are only realized in the home country is extreme. All that is needed is an asymmetry between the external effects on the human capital endowment for the home youth and for foreign youth.

${ }^{27}$ In general, $H_{t+1}=h_{t+1}^{0}(2+n) N_{t}$. Given our assumptions, this reduces to $H_{t+1}=h_{t+1}^{0}$. An alternative specification of the production function $Y=K^{\gamma} H^{\alpha} L^{1-\alpha-\gamma}$, where $L$ denotes raw labor growing at a constant exogenous rate $n$, would have resulted in virtually identical mathematics and results.

${ }^{28}$ This would e.g. be the case if debt is serviced with taxes on the middle-aged. 